\title{
盛土の情報化施工とその評価に関する研究 \\ STUDY ON MODIFIED METHOD OF DESIGN OF EMBANKMENT BY OBSERVATION DURING CONSTRUCTION
}

\author{
松尾稔*.川 村国 夫** \\ By Minoru MATSUO and Kunio KAWAMURA
}

\section{1. まえがき}

構造物を築造する場合，その施工中や施工後において しばしば各種の動態観測が行われる。その目的は, 多く の場合設計段階で予期した強度や変形に対比して, 構造 物の実際挙動が安全側にあることを確認するところにあ る。動態観測のこのような一般的な利用法は設計, 施工 の安心度を側面から保証するといら意味で，いわば消極 的な立場であるといえる。これに対し，動態観測から得 られる情報によって当初の設計を検討し直し,より合理 的になりうるならば施工中の設計変更をも避けないとい う積極的な立場がありうる。このような設計, 施工の概 念を情報化施工とよぶのである。

盛土のような土構造物の顕著な特徴として, 橋梁など 他の構造物に比べ, 施工中の設計変更が比較的容易なこ とをあげることができる。すなわち，盛土は動態観測を 上述の後者の立場で位置づけうるきわめて有利な構造物 であり，現実にこのような積極的立場で動態観測が実施 された例むある。本論文は同様の積極的な見地から，軟 弱地盤上の盛土を例に, 設計における動態観測の意義と 位置づけをまず明確にする。ついで動態観測を確率論的 な信頼度で評価しうる方法論を述べるとともに, 破壊予 知のために必要な観測とその結果に基ゔく施工管理図に ついての一試案を示す。また，最後に信頼度関数および 評価関数を使って盛土施工のモデルケースに関する試算 結果も示してある。

\section{2. 動態観測の意義と位置づけ}

\section{（1）動態観測の意義}

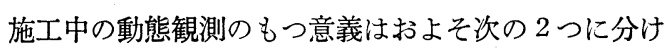

* 正会員 工博 名古屋大学助教授 工学部付属土圧研究施 設

** 正会員 農修 名古屋大学助手 工学部付属土圧研究施設
て考えることができる。すなわち，

a) 設計に際し技術者はまず，複雑な実際問題を計算 可能な理想問題に 置き換え (工学的判断), この簡単化 された仮想的現象に対して種々の設計計算を行うことに なる。すなわち，実際現象と計算結果の間には大きなギ ヤップが存在する。一方, 計算に必要な土質諸係数を求 めるための調查や試験にも作業の単純化と画一化の制約 がある。そのため, 調査や試験から得られる係数は実際 現象におけるそれとはもちろんのこと，理想化された仮 想的現象のそれとも一般に合致しない。簡単に“設計” と称している過程の中には，このように二重の不確定性 が入ってくる。しかし, 施工中の動態観測によりこの不 確定性に対処することができる。

b) 現在施工中の工事には直接的には不必要であって も，将来の同種の設計，施工に有益な情報となりうる。

建築物や橋梁では, 一般に施工段階での設計変更は多 大の困難と損失を伴う。これに対し, 土構造物では施工 途中の設計変更が比較的容易な点に顕著な特徴があるこ とを述べたが, この特徵を積極的に生かすという意味で 本論文において必要とされるのは上述 a) の意義をもっ た観測である。

さて, 信頼性解析に基づく最適設計の対象として多段 載荷工法による盛土施工を取上げ，適正な各段階の盛土 高さとその圧密放置期間を意思決定理論を用いて決定す る方法をすでに発表した ${ }^{1)}$ 。れは盛土完成までの全工 程（全体システム）に関する概略的な適正解の決定法で あり，いわば基本設計ともいうべきものである。したが って文献 1) においても明らかにしたように, 各盛土段 階に関する上記の決定にはある程度の不確定性が含まれ ることは避けられない。この不確定性に臨機応変に対処 し，全体システムに関する決定結果をより合理的に運用 していくためには，サブシステムともいうべき各段階盛 土の施工過程に設計变更を含む弾力性をもたせることが 必要である。このために, 施工中の動態観測が必須とな るのである。本論文で主として議論されるのは，上記の 
意味でのサブシステムの役割と内容である。具体的にい らと, 動態観測の結果に基づき各盛土段階での設計変更 の是否を検討し，変更が必要ならばその適正な対策工と 規模を決定する方法が述べられる。

\section{（2）動泸観測の位置づけ}

多段載荷工法による盛土の施工を模式的に表わすと, Fig. 1 のようである。各段階の盛土高さ $H_{\mathrm{I}}, H_{\text {II }}, H_{\text {III }}$, $\cdots$ と圧密放置期間 $T_{\mathrm{I}}, T_{\mathrm{II}}, T_{\mathrm{III}}, \cdots$ は前述した全体シス テムとしての基本設計において決定されている。本論文 で取扱らのはサブシステムとしての各段階内部の問題で あるが，動態観測によって基本設計の一部が変更される ことがありうるわけである。なお，各段階での所定高さ

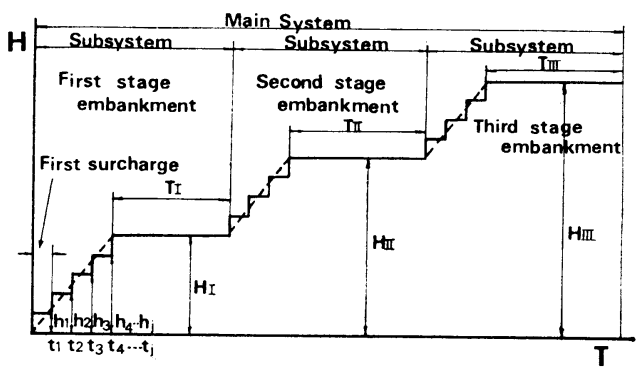

Fig. 1 Multistaged construction of embankment

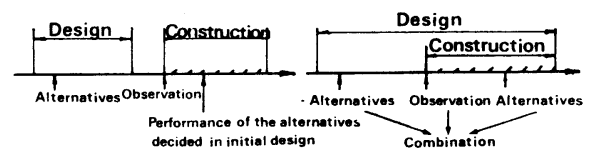

(a) Ordinary method (b) Observational method

Fig. 2 Concept of multistaged construction of embankment

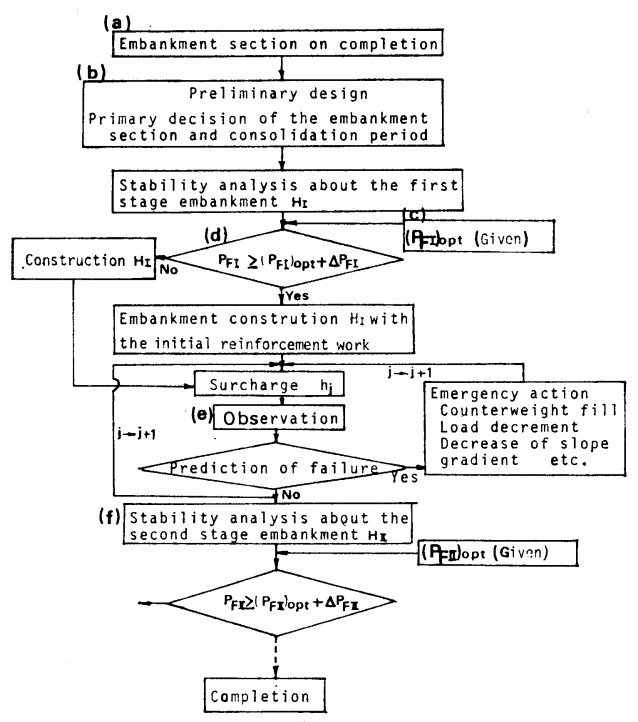

Fig. 3 Flowchart of observational method
までの盛立ては図の点線で示すように時間に対しほぼ直 線的に行われるが，ここでは簡単のため $h_{1}, h_{2}, h_{3}, \cdots$, $h_{j}$ のよ5に瞬間的載荷によって階段的に立ち上がるも のとする。また用語の混乱を避けるため, $h_{1}, h_{2}, h_{3}, \cdots$, $h_{j}$ の盛土に関しては 1 次, 2 次, 3 次 $\cdots j$ 次載荷とい うようによぶことにする。

\section{3. 動態観測と情報化施エについて}

従来の一般的な設計，施工の方法を時間を横軸にとっ て示すと Fig. 2 (a) のようであり, 設計段階と施工段 階とが分離, 独立しているのが普通である。所定の機能 を有する盛土築造のための種々の工法, たとえば押光盛 土をするとか，地盤改良をするとかの各種代替案の選択 は施工段階とは関連なく設計段階で決定される。そのた め動態観測は単に施工中の破壊や変位をチェックするた めの消極的な手段となり，その結果の具体的な行動はす でに設計段階で決定されているか，もしくは施工中の緊 急的な措置にとどまる。

一方, Fig. 2 (b) は動態観測を設計, 施工に積極的 に取入れた場合の概念図である。すなわち, 盛土施工の 全工程を設計段階とみなし，その一部に施工段階を含め て考える点に特徵がある。ここでは，動態観測およびそ の結果として考慮される対策工は, 設計の初期段階にお ける種々の対策工とまったく同等の立場の代替案として 位置づける。換言すると，机上設計の段階で考虑された 種々の対策工と施工開始後新たに必要となった対策工は まったく同等の立場にある代替案の集合であると考光， これらの代替案の合理的な組合せをダイナミックな姿勢 で選択していこうとするものである。

情報化施工の具体的なフローチャートを Fig. 3 亿示 す。簡単に説明すると以下のようである。

a) 路線選定を含む上位計画において, 完成後の盛土 の天端幅と高さが決まる。

b）完成までを何段階に 分けて盛立てるか，すなわ ち, 各段階の盛土高さと圧密放置期間の概略的な適正値 が基本設計において決定される。このとき，各段階盛土 の破壊確率 $P_{F \mathrm{I}}, P_{F \mathrm{I}}, \cdots$ の概値が計算されていること はいうまでもない2。

c）盛土の重要度に関する過去の実績をもとに, 対象 とする第 I段階盛土の適正な破壊確率 $\left(P_{F \mathrm{I}}\right)_{\mathrm{opt}}$ を与件 として与える ${ }^{3)}$ 。

d) 動態観測によって低減しうる破壊確率を $\Delta P_{F \mathrm{I}}$ と し, $P_{F \mathrm{I}}$ と $\left(P_{F \mathrm{I}}\right)_{\mathrm{opt}}+\Delta P_{F \mathrm{I}}$ を比べる。 $P_{F \mathrm{I}} \leqq\left(P_{F \mathrm{I}}\right)_{\mathrm{opt}}$ $+\Delta P_{F \mathrm{I}}$ ならば新たな対策工を講ずることなく, $H_{\mathrm{I}}$ を 施工し，同時に動態観測を行う。

一方, $P_{F \mathrm{I}}>\left(P_{F \mathrm{I}}\right)_{\mathrm{opt}}+\Delta P_{F \mathrm{I}}$ であるなら, たとえ動 
態観測を行っても $H_{\mathrm{I}}$ の盛土の破壊確率を適正値以下に 抑えることができないわけであるから，押え盛土や地盤 改良などの別の対策工を盛土施工前あるいは施工と同時 に実施しなければならない。その規模は少なくとも破壊 確率を $P_{F \mathrm{I}}-\left\{\left(P_{F \mathrm{I}}\right)_{\mathrm{opt}}+\Delta P_{F \mathrm{I}}\right\}$ だけ低減させる範囲 で与えられる。

e） $H_{\mathrm{I}}$ の施工開始と同時に動態観測を行い, 破壊の 兆候をチェックする。 $H_{\mathrm{I}}$ の盛土施工中, 観測量がある 危険量に達しなければ, 次の載荷盛土に移ればよく, 最 終次載荷盛土であれば, 所定の放置期間をとってそのま ま第段階の盛土に移ればよい。しかし，破壊が予知さ れれば規定時間内（恐らく数時間内）で対策工を実施し なければならない。対策工としては, 押え盛土, 本体盛 土の一部除去, 斜面勾配緩和, シートパイル打設など施 工中でも可能で，かつ迅速にできるものが考えられる。 なお, 対策工の最適規模の決定, 破壊予知の方法などに ついては後述する。

f）以下同様にして第I段階から最終段階まで進め, 盛土を完成させる。

\section{4. 情報化施工の信頼性解析}

\section{(1) 盛土の力学的な信頼度}

Fig. 1 に示すように, 各段階での盛土は $h_{1}, h_{2}, \cdots, h_{j}$ というように段階的に盛上げていくと考える。このとき $h_{j}$ の盛土は, その前の $h_{j-1}$ の盛土が動態観測によって 破壊しないと判断されたのちに施工されることになる。 したがって, $j$ 次載荷盛土の破壊確率 $P_{F}$; 実状に最 も忠実な形で定義すると次のようになる。

$$
P_{F j}=P_{\mathrm{rob}}\left[P_{F}\left(h_{j}\right) \mid R\left(h_{j-1}\right)\right] \cdots
$$

ここに,

$P_{F j}: j-1$ 次載荷盛土が 無事立ち上がったのち に $j$ 次載荷に上って破壊する確率

$R\left(h_{j-1}\right): j-1$ 次載荷の盛土が安全に立ち上がる信 頼度

$P_{F}\left(h_{j}\right): j$ 次載荷時に $\left(h_{j}-h_{j-1}\right)$ の高さだけ瞬間 載荷した場合の破壊確率

である。

ところが，式 (1) の $P_{F j}$ は現実には計算することが できない。理由は次のとおりである。飽和粘土地盤上の盛 土の破壊を考えるとき，その破壊面上のせん断応力 $s$ と これに抵抗する非排水強度 $c_{u}$ はともに確率変量となる。 そしてわれわれは，土質調查を行うことにより，事前に これら $s, c_{u}$ の確率分布だけは知ることができる。しか し, 所定の盛土 $h_{j-1}$ が無事立ち上がった場合 (この事 実は $s, c_{u}$ の事前分布からある確定值 $s_{d}, c_{u d}$ が実現し,
かつ $s_{d}<c_{u d}$ であることを示す), 実際に出現した実現 值 $s_{d}, c_{u d}$ の具体的な大きさを知ることはできない。す なわち, たとえ $j$ 次載荷 $\left(h_{j}-h_{j-1}\right)$ によるせん断応力 の増分 $\Delta s$ を確率的に推測したとしても， $c_{u d}-\left(s_{d}+\Delta s\right)$ を具体的に計算することができないので, 式 (1) の $P_{F}$ $\left(h_{j}\right)$ すなわち $P_{F j}$ を求めることができない。

また, かりに式 (1) の $P_{F j}$ が何らかの方法によって 算出できたとしても，以下のような実務上の難点があ る。情報化施工の方法論の眼目は, 動態観測の結果によ り施工中の盛土に破壊の危険が生じたと判断したとき, 適正な対策工の規模と種類を迅速に決定し，実施するこ とである。このとき，第 $1,2, \cdots, j-1, j$ 次載荷におけ るそれぞれの適正な対策工の規模や種類が計算上異なっ たとしても, 対策工のための施工機械や労働力をその都 度編成しなおすということは実際的でない。なぜなら実 務上一般に $j-1$ 次載荷から $j$ 次載荷に移るまでの間隔 はたかだか数日あるいはそれ以内であるのが普通だから である。したがって, 現実問題としては, 盛土を開始し たならば, もはやその途中で評価計算をしたのちその都 度対策のための機械や労働力を急ぎ準備する，というこ とは実際には不可能であり, 各段階の盛土開始前の時点 で各次載荷時の最適な対策工を決定しておかなければな らない。すなわち, 後述の数值計算例に示したように, 各次載荷に関し，もし破壊の兆候があらわれた場合の最 適対策工を事前に計算しておかざるをえない。このよう な観点より，第 1 近似として $P_{F j}$ は, $j$ 次に盛土高 $h_{j}$ が瞬間載荷されたと考えたときの破壊確率に等しいと仮 定する。この仮定に起因して発生する不確定性は, すで に2.(1)で述べたように施工中の動態観測がカバーして ゆく立場にたつ。

さて, 各次載荷盛土の信頼度については, 次のように 考える。情報化施工では, 破壊の兆候がみえても施工中 に対策工を講ずることができるので，この系の信頼度は 保全度を伴う信頼度として扱うことができる。すなわ ち, 系の信頼度は, 盛土本体が対策工なしの状態で破壊 しないといら信頼度と, 破壊状態をなるべく早く正常状 態に引き戻寸能力を備えた保全度の和と考えることがで きる。これを式で表わすと

$A_{j}=R_{j}+[k] M_{j}$

各記号の内容は以下のとおりである。

$A_{j}: j$ 次載荷によって盛土が破壊しない系全体 の信頼度。ただし $j-1$ 次載荷盛土が立ち 上がったのち, $j$ 次載荷盛土を実施すると きの信頼度を意味する。

$R_{j}:$ 同じく $j$ 次載荷盛土を施工するときの信頼 度であるが,この中には $j$ 次載荷時におけ る動態観測の効果としての保全度は含まれ 
ない。すなわち, $R_{j}=1-P_{F j}$ である。た だし，第 1 次載荷盛土の施工前，あるいは 施工と同時に初期対策工が実施された場合 には、これらによって向上する信頼度が当 然 $R_{j}$ の中に含まれている。

$M_{j}: j$ 次載荷盛土中の動態観測の結果, 実施さ れた対策工により向上する系の信頼度。た だし，その対策工は別に定められた時間 $\Delta t$ 以内で実施できるものとする。

$[k]$ : 動態観測によって盛土が破壊しないと結論 を得たときは $k=0$, 破壊するといら結論を 得たときは $k=1$ となる。

動態観測の結果破壊するという結論を下したときはい つでも $M_{j}$ を得るだけの施設, 資材, 労働力が確保され ているので, この意味から系としての信頼度は $k=1$ と して与えられるものである。したがって，破壊しないと いら結論を下しえた場合には， $j$ 次載荷盛土を $R_{j}$ だけ の信頼度でっくりあげたことになる。

\section{（2） 経済的評価モデル}

盛土を経済的に評価するためには, 費用関数の確立が 必要となる。そのため情報化施工の経済的評価モデルを 次のように考える。

$$
\begin{aligned}
\sum_{j} C_{A j}= & \sum_{j} C_{C j}+\sum_{j} C_{O j}+\sum_{j} C_{W j} \\
& +P_{k=1} \sum_{j} C_{M j}+\left(1-A_{j}\right) \sum_{j} C_{F j} \cdots
\end{aligned}
$$

ここに,

$\sum_{j} C_{A j}$ : 信頼度 $A_{j}$ で $j$ 次載荷盛土までを施工する のに要する費用総額。

$\sum_{j} C_{C j}: j$ 次載荷盛土まで施工するのに要する建設 費。ただし，1 次載荷前，または 1 次載荷 と同時に施工される地盤改良などの初期対 策工は $C_{C_{1}}$ に含まれるが，動態観測によっ て実施される $j$ 次載荷時の対策工費は含ま れていない。

$\sum_{j} C_{O j}: j$ 次載荷盛土までに必要となる動態観測 費。

$\sum_{j} C_{W j}$ : 盛土が破壊する，しないの決定にかかわら ず， $j$ 次載荷盛土まで，常に確保しておか なければならない対策工のための資材，施 工機械, 労働力などの待機損失費。ただし 各次載荷時の最適な対策工の規模は，それ ぞれの載荷時で変化するため, 厳密には施 工機械や労働力の確保は各次載荷時で常に 再編成しなければならない。しかし，盛土 の進行とともにこれらを再編成するといら ことは，あまり現実的ではないので，対策
工の規模がもっとも大きくなる載荷時の待 期損失費を全過程を通じて見込むのも一つ の方法である。

$\sum_{j} C_{M j}: j$ 次載荷時に動態観測によって破壊すると いう結論を得て，対策工を実施するときの 対策工費。

$P_{k=1}: j$ 次載荷時に $k=1$ が発生する確率。ただ し $P_{k=1}$ は盛土の施工前に検討するため, $h_{j}$ を瞬間載荷した場合の破壊確率と考え， 近似的に $P_{F} j$ とみなすことにする。

$\sum_{j} C_{F j}$ : 破壊損失費。破壊損失費の内容に関しては

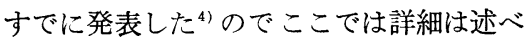
ないが，基本的には以下の立場をとる。

（a）破壊後再建される盛土断面は当初予 定のものと同一とする。（b）損害賠償費 については, 物件損害の場合は原型復旧を 原則とする。また厳重な施工管理により人 命損失は起こさないものとする。

なお，破壊損失費に関しての具体的な取扱い方は後章 の数值計算例でもう少し詳細に述べる。

\section{（3）評価基準と信頼性解析}

上位計画では，非経済的問題も含めた総合的な評価が 要求されるが，下位計画になればなるほど数少ない評価 基準で決定を下して，合理的である。この意味で，本論 文で取扱っているような下位の実施計画では，客観的か つ定量的表現が可能な費用便益基準，中でも便益一定， 費用最少の基準を採用することは許されるであるう ${ }^{16)}$ 。

さて, 動態観測の結果設 計変更の可能性が生じた場 合, いかなる対策工を, どの程度の規模で実施すればよ いかが信頼性解析の目的となる。Fig. 4 は信頼性解析 に基づて $j$ 次載荷時の最適な信頼度 $\left(A_{j}\right)_{\text {opt }}$ を求め る概念図である。すなわち，横軸に盛土の信頼度 $A_{j}$, 縦軸に信頼度 $A_{j}$ を得るための総費用 $\sum_{j} C_{A j}$ がとって ある。いまかりに, $j$ 次載荷盛土の安全性に関して大き な信頼度を期待しようとすれば，対策工費は大きくなる が，反面破壊による期待損失費は小さくてすむ。一方，

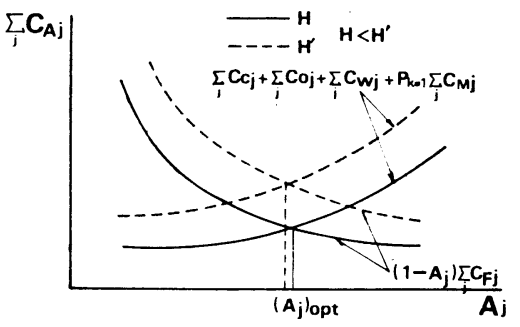

Fig. 4 Relationship between the reliability $A_{j}$ and the total cost $\sum_{j} C_{A j}$ 
小さな信頼度で施工することを許容すれば，対策工費は 安くなるが, 逆に, 破壊による期待損失費は高くなる。 この結果全費用 $\sum_{j} C_{A j}$ が最小となる信頼度 $\left(A_{j}\right)_{\mathrm{opt}}$ が 存在し, 式 (2) による $R_{j}$ と $\left(A_{j}\right)_{\text {opt }}$ の差として最適 な対策工の規模 $\left(M_{j}\right)_{\mathrm{opt}}$ と, その種類が決定できるこ とになる。この作業を各次載荷の盛土高 $\left(h_{1}, h_{2}, \cdots, h_{j}\right)$ に対して実施し, 求められた保全度 $\left(M_{j}\right)_{\text {opt }}$ と $\left(M_{j}\right)_{\text {opt }}$ を迅速に確保するための対策工の種類, ならびにその実 施方法を表にまとめる。事前に準備されたこの表を参考 にして, 逐次盛土を施工していくことになる。具体的な 方法は数值計算例をあげてのちに示す。

\section{5. 破壞の評価時期とその方法}

動態観測から得られる連続的な情報によって盛土の力 学的な安全性の評価が可能かどうか, もし破壊の可能性 があるならばその時期を適確に予知しらるかどらかとい う点が, 情報化施工システムの有効性を決定するキーポ イントとなる。そのため破壊予知の手段として地盤のい かなる量を動態観測し, その量がいかなる限界值に達し たならば破壊状態になるかを検討しなければならない。

従来から盛土の破壊予知に関して種々の観測が行われ ている。土圧や間隚水圧測定などはその一例であるが， 計器の埋設や精度あるいは応力集中やタイムラグなどの 問題があり, “適切かつ迅速な予知”という面では難点 がある。これに対し, 変位の測定は比較的容易で精度も よい。さらに, 変位や変位速度は破壊現象ときわめて直 接的に関係する。このことから, 盛土のすべり破壊に関 しては変位および変位速度で施工管理を行うのが妥当と 思われる。この場合, 軟弱地盤上に建設された盛土のす ベり破壊に関しては, 基礎地盤のせん断変位が重要な指 標になるため, 基礎地盤の沈下量と側方変位量によって 破壊予知を行うのが適当と考えられる。

Fig. 5 は, 以上の観点から軟弱地盤上に施工された 盛土の破壊例, および破壊しなかった例の変位過程をま とめたものである。すなわち, 横軸に盛土のり尻におけ

る基礎地盤の側方変位量 $\delta$ と盛土中央部直下の基礎地盤 の沈下量 $d$ の比 $(\delta / d)$ をとり, 縦軸に $d$ をとって施工 中の変位過程をまとめたものである。

図中の各盛土は, その盛土断面や単位体積重量が異な ることはもちろん, 基礎の軟弱地盤の性質もそれぞれに 異なっていることに注目したい。すなわち，Fig. 5 に よれば, 条件の異なる種々の破壊例が大体図中に示した 曲線上で破壊に至っていることがわかる。しかも, 破壊 例の変位過程をよくみると, 盛土の進行とともにこの曲 線に近づき，たとえばのちの Fig. 7 と対比するように この曲線に近づくほど変位の時間的変化 (変位速度) が 大きくなることが明らかである。

一方, 破壊しない例では, 一般的に施工直後ではこの 曲線に近づく傾向を示すが，施工途中からは側方変位よ り沈下量の方が卓越してむしろこの曲線から遠ざかる傾 向を示すことに注目すべきである。すなわち, 側方流動 より圧密沈下が卓越しつつあることを示している。以上 の説明から，この曲線を一つの破壊規準線とみなせば,

Fig. 5 は動態観測による破壊予知のための施工管理図 としてきわめて有望な図と考えられる。なお,この曲線 を近似的に式で表わせば次のようになる。

$$
d=4.95 \exp \{-2.28(\delta / d)\}
$$

たとえば, 破壊例として月寒川盛土について考えてみ $ろ^{6)}$ 。この盛土は媣さ約 $6 \mathrm{~m}$ ほどの軟弱な泥炭上に施工 された試験盛土である。基礎地盤の土質調査結果（コー ン指数) の代表的なものを Fig. 6 に示し, さらに施工 速度および基礎地盤の盛土中央下の沈下量, のり尻の側 方変位量についても Fig. 7 に示してある。施工報告に よれば, 盛土荷重が時間的に増大するにつれて沈下量お よび側方変位量は徐々に進行し, 施工後 14,15 日目に かけて盛土斜面およびのり尻に無数のクラックが発生し た。しかしそれにもかかわらず, 盛土載荷を続行した結 果, ついに 16 日目にはのり尻が大きく流動し, 盛土本 体が完全に沈下しながら崩れたと報告している。この施 工過程を先に述べた座標系でプロットしたのが Fig.5

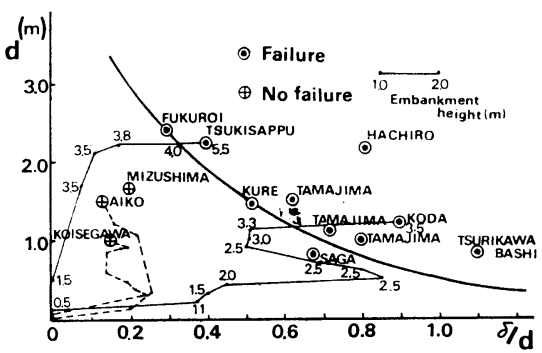

Fig. $5(\delta / d \sim d)$ plots for prediction of failure

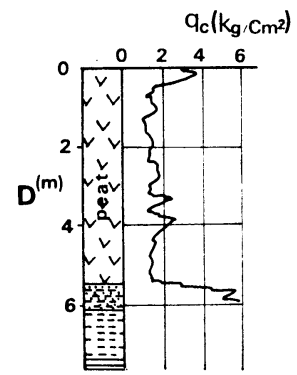

Fig. 6 An example of sounding data $q_{c}$ at Tsukisappu

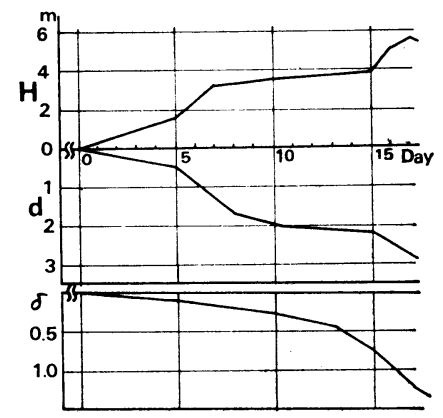

Fig. 7 Progress of settlement $d$ and flow $\delta$ to the height of embankment at Tsukisappu 


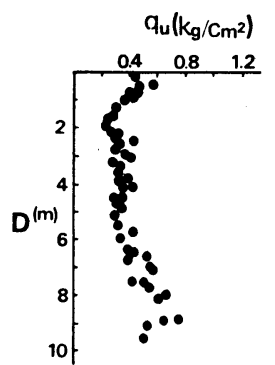

Fig. 8 An example of unconfined compression test result at Aiko (After Watanabe ${ }^{8)}$ )

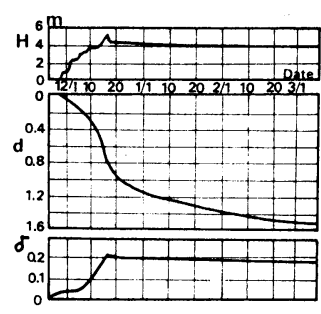

Fig. 9 Progress of settlement $d$ and flow $\delta$ to the height of embankment at Aiko (After Watanabe ${ }^{8)}$ )

に示してある。この図上で施工過程を詳紐に見てみると 以下のようである。まず, 施工直後においては, 勾配の 大きい変位過程の傾向を示している。これは, 基礎地盤 の初期間隊比 $e_{0}$ が非常に大きい $\left(e_{0} \doteqdot 15\right)$ ことに加え， 圧縮指数 $C_{C}$ もきわめて高い $\left(C_{C} \doteqdot 8\right)$ ことに帰因して, 初期の段階においては側方流動よりむしろ圧密沈下の方 が卓越したためと思われる。 5 日間の放置期間後再度盛 土載荷を行ったところ, 今度は側方変位が急激に増大 し, 図に示したように変位過程は横軸とほとんど平行に 進んでいる。そしてこのときに前述したような明らかな 破壊の兆候が出現したわけである。さらに変位過程はそ の時間的変化を増加させながらそのまま進み,ついには 式 (4) の破壊規準線上で破壊に至ったことがわかる。

同様な破壊例として幸田盛土について見てみる。この 試験盛土は有機質地盤上に施工された ${ }^{7)}$ 。報告書による と,施工は当初連続的に約 2 週間かかって行われたが,盛 土高が約 $2.5 \mathrm{~m}$ に達した時点ですべり面が認められる ほどの破壊の兆候を示した。そこで, 破壊の進行を止め るため約 3 か月間の放置期間を設けて地盤強度の上昇を はかったのち盛土施工を再開した結果, 突如盛土斜面に 大きなき裂が発生し, 急激な側方変位の増大をともない ながら完全に破壊したと報告されている。さて,この過 程を Fig. 5 上でみてみる。初期の連続的な盛土に対し て変位過程は施工経過時間とともに直線的に破壊基準線 に近づいている。このことは, 圧密沈下に比べて側方流 動がかなり大きいことを示すにほかならない。ついで 3 か月間の放置期間においては, 地盤の圧密が進行し変位 過程は逆に破壊基準線から遠ざかる傾向を示している。 さらに盛土再開後には，図から明らかな ように変位過程は再びほぼ水平に破壊規 準線に向い，ついにこの線上で終局的な 破壊が生じていることがわかる。図の繁 雑さを避けるために, 変位過程は省略し てあるが，Fig. 5 に示した他の破壊例 における傾向も大同小異である。

Table 1 Undrained strength $C_{u}$ and compaction density $\gamma_{b}$ for numerical example

この章では段階的施工のモデルケースを設定し，既述 した方法論にしたがって, 各次載荷盛土時における系の 最適な信頼度および対策工の種類, 規模の決定に検討を 加える。

\section{（1）盛土の形状その他}

いま, Fig. 10 に示すように上位計画から次の事項が 工期の制約と安全性の観点より決定されたとする。

(1) 盛土の本体断面は高さ $7.0 \mathrm{~m}$, 天端幅 $10.0 \mathrm{~m}$, 斜 面勾配 1.25 の台形断面として盛土延長は $500 \mathrm{~m}$ とす

\begin{tabular}{l|c|c|c|c|c|c}
\multicolumn{2}{c|}{ Stage } & \multicolumn{2}{c|}{ First stage } & \multicolumn{2}{c|}{ Second stage } & \multicolumn{2}{c}{ Third stage } \\
\cline { 2 - 7 } Statistics & $\begin{array}{c}c_{u} \\
\left(\mathrm{t} / \mathrm{m}^{2}\right)\end{array}$ & $\begin{array}{c}\gamma_{b}^{b} \\
\left(\mathrm{t} / \mathrm{m}^{3}\right)\end{array}$ & $\begin{array}{c}c_{u} \\
\left(\mathrm{t} / \mathrm{m}^{2}\right)\end{array}$ & $\begin{array}{c}\tau_{b}^{b} \\
\left(\mathrm{t} / \mathrm{m}^{8}\right)\end{array}$ & $\begin{array}{c}c_{u} \\
\left(\mathrm{t} / \mathrm{m}^{2}\right)\end{array}$ & $\begin{array}{c}\gamma^{b} \\
\left(\mathrm{t} / \mathrm{m}^{3}\right)\end{array}$ \\
\hline Mean & 1.20 & 1.75 & 1.80 & 1.75 & 2.30 & 1.75 \\
Standard diviation & 0.38 & 0.13 & 0.58 & 0.13 & 0.81 & 0.13 \\
Coefficient of variation & 0.317 & 0.070 & 0.320 & 0.070 & 0.351 & 0.070 \\
\hline
\end{tabular}




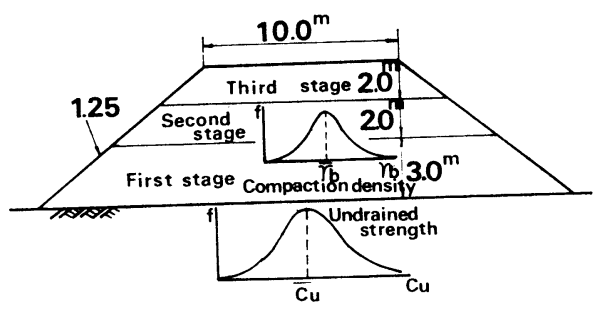

Fig. 10 The model embankment for numerical example

る。

(2) 盛土の施工計画は施工段階数を 3 段階とし, 各段 階の盛土高をそれぞれ $3.0 \mathrm{~m}, 2.0 \mathrm{~m}, 2.0 \mathrm{~m}$, 圧密放置 期間をそれぞれ 3 か月ずつとする。第 1 , 第 2 , 第 3 段 階の施工期間をそれぞれ 30 日，20日，20日とし，各段 階内部における各次載荷盛土の信頼度および対策工の検 討は, まき出し厚 $0.25 \mathrm{~m}$ 高さ区切りに対して行う。

(3) 各段階での適正な破壊確率 $\left(P_{F}\right)$ opt は上位計画 から 20\%，15\%，15\% と定められているとする。

(4) 盛土の単位体積重量 $\gamma_{b}$ および基礎地盤の非排水 強度 $c_{u}$ の分布は各段階盛土直前の調査で得られるもの として, Table 1 にまとめてある。ただしそれぞれの 分布は正規分布で近似できるものとする ${ }^{9), 12) ~ 14) 。 ~}$

(5) 盛土のすべりに対する検討は, 現行の円弧すべり による方法が適用できるものとする。

(6) 最適信頼度は総費用 $\sum_{j} C_{A j}$ 最少という評価基準 で決定されるものとする。

\section{（2）評価モデルについて}

式 (3) の経済的評価モデルにおける各費用項目につい ての立場と仮定は以下のとおりである。

a） 盛土建設費 $C_{C}$ について

盛土を施工する際に必要な建設費用の項目は, 各分野 において若干の相違はあるものの, 大きな項目では, 地 盤調查費, 材料費, 施工費, その他で分類されている。 特に施工費は, 工事費（調查費，土工費，のり面保護 費, 排水工費，函渠工費，その他），労務費，運搬費な どによって構成されているので各現場の条件によって大 きく変化する。この試算例では, 一応過去の同程度の規 模をもつ盛土施工の積算例 ${ }^{10)}$ を参考にして，第 1 段階盛 土高 $3.0 \mathrm{~m}$ に対して単位延長当たり 10 万円を基準とし, その他の各断面に対しても土工費, 労務費を考虑して積 算資料 ${ }^{11)}$ よ求めた。なお, 用地買収費は上位計画の段 階で終わっているものと考え, その費用は考慮しなかっ た。

b） 動態観測費 $C_{O}$ について

対策工を施工するか，否かの判定を下すため破壊の兆 候を常にチェックしなければならない。そのため施工期 間中動態観測に用いる測定器の費用およびその結果を常
に監視する人件費が必要となってくる。今回の試算例で は測定規模に関して，過去の破壊例を調査すると ${ }^{5)}$ ，破 壊延長はおよそ $20 \sim 120 \mathrm{~m}$ 程度であるため, 盛土延長 $20 \mathrm{~m}$ につき 1 箇所の沈下計を 盛土中央部の基礎地盤上 へ，また，左右のり尻付近に側方変位計を設置するもの とした。そのため設置箇所は 25 箇所で, 1 人の監視員 が 5 箇所を担当するものとして積算資料 ${ }^{11)}$ より人件費お よび測定器費を計算した。

c）施工機械, 資材および労働力の待機損失費 $C_{W}$ に ついて

対策工を実施するために必要な施工機械, 資材および 労㗢力が常に確保されていなければならないことは前述 した。現実には, 破壊の兆候が生じたならば他の現場で 作業している労働力, 資材および施工機械の一部を危険 箇所に投入するような手段を講ずることになるであろ う。そのため工事の進行が遅れたり, あるいは余分な労 働力を必要とすることになるのでそれに伴ら損失が生ず る。これが実際の $C_{W}$ に相当する費用と考えられるが, たとえば工期遅延による損失費を試算例で想定すること はかなりむずかしい。そこで試算例のモデルケースにお いては, 対策工に必要な施工機械や労働力は盛土本工事 とは別途に待期させる立場から積算資料 ${ }^{11}$ を参考に計算 した。

計算上は各次載荷盛士によって対策工の規模が変化す るため, 施工中常に確保しなければならない施工機械, 資材および労働力の量が変わる。一般的な問題として待 期量を常に変更するということは, 実務上問題が多いた め, 前にも述べた対策工の規模が最大となる盛土に必要 な量をその段階盛土施工中終始確保しておく立場で計算 することもできる。しかし，この試算例では各次載荷盛 土過程に弾力性があって, 数日間おきに対策工を決定す ることが可能な現場を想定して計算した。

d）対策工費 $C_{M}$ について

対策工を施工するにあたって留意すべきことは, 工事 工程, 取扱い土量, 土工機械の経済比較および現場条件 である。

工事工程に関しては, 破壊の生起が予想されれば数時 間以内で対策工が実施できることを原則としている。た とえば薄い砂のポケットやはさみ層などにおける急激な 間哾水圧の上昇によって生ずる急速破壊などは, 動態観 測によって対処できないので，このような破壊は地盤調 查の結果に基づいて事前に水抜きなどの対策が実施され ているものとし，この方法論では取扱わない。情報化施 工で取扱う破壊は, 変位が時間とともに徐々に進行し数 時間後に完全な破壊に至る場合を対象とする。

取扱い土量は破壊延長によって大きく異なる。盛土の 破壊延長は，前述したように大体 20〜120 m の規模で 
あり中でも $50 \mathrm{~m}$ 前後が最も多い。そこでこの試算では $50 \mathrm{~m}$ として計算を行った。

対策工別および土工機械別の経済比較の結果は以下の ようである。各次載荷盛土に関して費用計算を行うと, 第 1 段階最終次盛土の場合の対策工費がもっとも高くな るので, この場合についてのみ示したのが Fig. 11, 12 である (Table 3 参照)。なお検討した対策工の種類と 規模に関しては Table 2 に示した。

Fig. 11 は，それぞれの対策工を実施するにあたって 使用される土工機械の経済比較と土工量 $Q$ に対して行 ったものである。この場合対策工は 5 時間以内で実施で きるものとし，また規定の土工量を処理するのにもっと も経済的なケースについてプロットされている。たとえ ば，対策工として盛土荷重軽減をする場合を考えてみよ う。切削土工機械としてブルドーザを使用するとすれ

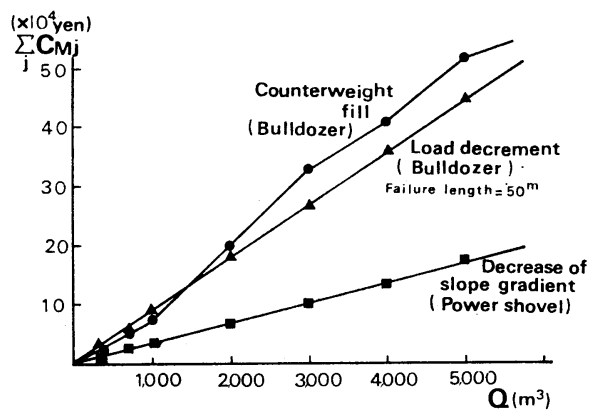

Fig. 11 Relationship between earthwork quantity $Q$ and emergency action $\operatorname{cost} \sum_{j=1}^{12} C_{M j}$

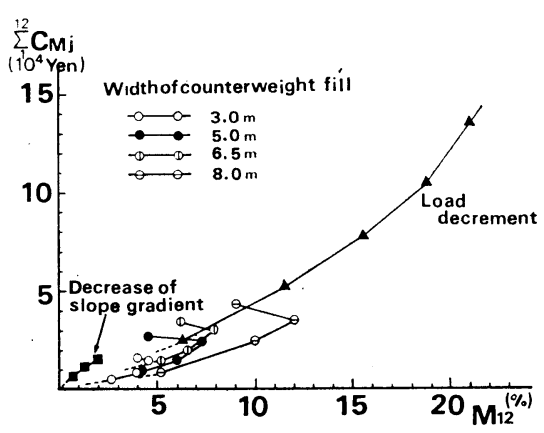

Fig. 12 Relationship between cost $\sum_{j=1}^{12} C_{M j}$ and reliability $M_{12}$ increased by emergency action

Table 2 Emergency actions for numerical example

\begin{tabular}{|c|c|c|c|c|c|c|}
\hline \multicolumn{2}{|c|}{ Emergency action } & \multicolumn{5}{|c|}{ Scale } \\
\hline \multirow{2}{*}{$\begin{array}{l}\text { Counter- } \\
\text { weight } \\
\text { fill }\end{array}$} & Height $(\mathrm{m})$ & 0.5 & 0.8 & 1.3 & 1.5 & \\
\hline & Width (m) & 3.0 & 5.0 & 6.5 & 8.0 & \\
\hline \multicolumn{2}{|c|}{$\begin{array}{c}\text { Decrease of slope } \\
\text { gradient }\end{array}$} & 2.5 & 1.50 & 1.80 & 2.00 & \\
\hline \multicolumn{2}{|c|}{$\begin{array}{l}\text { Load decrement }(\mathrm{m}) \\
\text { (Cutting height) }\end{array}$} & 0.25 & 0.50 & 0.75 & 1.00 & 1.50 \\
\hline
\end{tabular}

ば，たとえば $3000 \mathrm{~m}^{3}$ の土量を切削するのに次の方法 が考えられる。すなわち， $6 \mathrm{t}, 11 \mathrm{t}, 15 \mathrm{t}, 21 \mathrm{t}$ 級ブルド 一ザを積算資料 ${ }^{11}$ を参考にしてもっとも経済的に組合わ せると $21 \mathrm{t}$ 級 13 台, $6 \mathrm{t}$ 級 1 台の組合わせとなる。した がって,これらの施工機械をそれぞれ 5 時間ずつ運転す るのに要する費用が Fig.11にプロットされているわけ である。

Fig. 12 は，Fig. 11 の土工量と土工費の関係を利用 して Table 2 のそれぞれの対策工を実施することによ って向上する信頼度 $M_{j}$ と, それに要する対策工費（土 工費） $\sum_{j} C_{M j}$ の関係を示したものである。 $M_{j}$ として は,先に述べた理由により最大の対策工費を与える第 12 次載荷盛土 $M_{12}$ の場合が採用されている。なお経済比 較の具体的な検討については次の現場条件とあわせて以 下に述べる。

現場条件については多くのことが考えられるが，たと えば以下に示すような点をあげることができる。上述の

Fig. 11，12 には対策工を実施するにあたって必要とな る用地費，材料費および運搬費は含まれていない。すな わち, このモデルケースで対象とした現場は, 土取り場 が現場内に存在するものとし, 対策工に必要な材料は早 急に調達が可能で, しかもその運搬もダンプトラックを 必要としない現場に限定した。換言すると, 盛土施工現 場内で切盛りによって余分な土が容易に入手できるよう な現場を想定したわけである。しかし，実際には土取り 場が施工現場からかなり離れているケースも多いから， このような現場条件に対しては, Fig. 11，12 を材料費 や運搬費などを考慮して作成する必要が生ずる。また， 土取り場が非常に遠いため対策工の早急な実施が不可能 である現場条件に対しては, たとえば盛土本体の天端を 切削したり，斜面勾配を緩和したりする方法も検討され ねばならない。要は, 各現場管理者がその現場条件に応 じて考えうるすべての対策工について Fig. 11，12のよ うな検討を実施すればよいわけである。

以上のように, 現場条件によって結果は種々異なるけ れども本試算例のような条件に対しては以下のようなこ とが明らかである。すなわち, Fig. 12 によって $M_{12}$ と $\sum_{j=1}^{12} C_{M j}$ はおよそ比例関係にあり, 対策工のうち勾配緩 和と押え盛土は $M_{12}$ が小さい範囲で有効となり, 盛土 荷重軽減はいかなる $M_{12}$ にも対応できることがわかる。 また注目すべき点として，押え盛土幅をかなり大きくと れる場合には (今回の試算例では $8.0 \mathrm{~m}$ まで), 押え盛 土高を大きくするよりもむしろ押え盛土幅を大きくした 方が有利であることをあげることができる。さらに対策 エとしての押え盛土は, 他の対策工に比べて経済的であ ることも理解できる。

e）破壊損失費 $C_{F}$ について 
たとえ対策工を実施したとしてもなお破壊する可能性 は存在する。破壊損失費には, 再調査費, 再建費, 整地 費, 地盤改良費, 損害賠償費などが含まれているが, そ

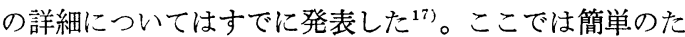
めに再調查費 0.5 万円 $/ \mathrm{m}$, 再建費は盛土建設費と等しく し，整地費は積算資料 ${ }^{11}$ より 120 円 $/ \mathrm{m}^{3}$ とした。また， 地盤改良にはサンドコンパクションパイルを打設するも のとした。すなわち, 直径 $40 \mathrm{~cm}$, 長さ $12.5 \mathrm{~m}$ のサン ドパイルを用い，砂置換率 $15 \%$ と想定して積算資料 ${ }^{11)}$ より計算したところ単位破壊延長当り 25.2 万円となっ た。さらに損害賠償費は盛土が圈場中を通過するものと 考え，農作物被害による賠償と， $1 \mathrm{~m}^{2}$ 当り 0.4 万円の 農地を単位延長当り $20 \mathrm{~m}^{2}$ 買収するといら方式で算定し た結果 12 万円 $/ \mathrm{m}$ となった。

\section{（3）試算結果}

式（2）と式（3）を組合わせることによって各次載荷 断面の最適な信頼度および対策工の種類, 規模が決定で きる。

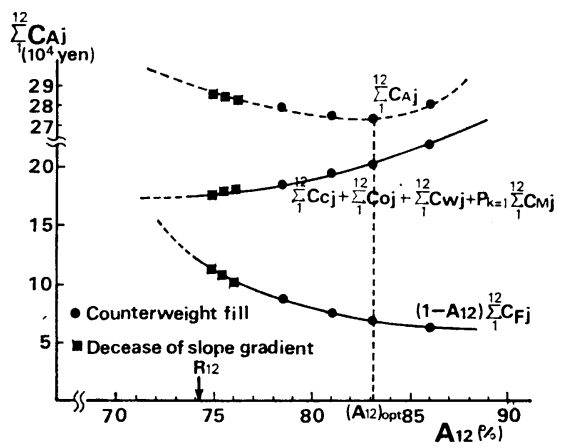

Fig. 13 An example of results in reliability analysis

Table 3 Results of numerical example

(a) First stage embankment

\begin{tabular}{|c|c|c|c|c|c|c|c|c|c|c|}
\hline \multicolumn{4}{|c|}{ Surcharge number } & 3 & 6 & 8 & 9 & 10 & 11 & 12 \\
\hline \multicolumn{3}{|c|}{ Embankment height } & (m) & 0.75 & 1.50 & 2.00 & 2.25 & 2.50 & 2.75 & 3.00 \\
\hline \multirow{5}{*}{ 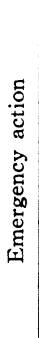 } & \multicolumn{3}{|c|}{ Method } & & $\begin{array}{l}\text { Counter- } \\
\text { weight fill }\end{array}$ & $\begin{array}{l}\text { Counter- } \\
\text { weight fill }\end{array}$ & $\begin{array}{l}\text { Counter- } \\
\text { weight fill }\end{array}$ & $\begin{array}{l}\text { Counter- } \\
\text { weight fill }\end{array}$ & $\begin{array}{l}\text { Counter- } \\
\text { weight fill }\end{array}$ & $\begin{array}{l}\text { Counter- } \\
\text { weight fill }\end{array}$ \\
\hline & \multirow{2}{*}{ Scale } & Height & (m) & & 0.6 & 0.8 & 0.9 & 1.0 & 1.1 & 1.2 \\
\hline & & Width & (m) & & 3.0 & 5.0 & 8.0 & 8.0 & 6.5 & 6.5 \\
\hline & \multicolumn{3}{|c|}{$\begin{array}{l}\text { Construction equipment } \\
\text { (Bulldozer) }\end{array}$} & & $\begin{array}{c}11 \mathrm{t} \text { class } \\
1\end{array}$ & $11 \mathrm{t} \underset{2}{\text { class }}$ & $\begin{aligned} & 15 \mathrm{t} \text { class } 1 \\
& 1 \\
& 11 \mathrm{t} \text { class } \\
& 1 \\
& 6 \mathrm{t} \text { class } \\
& 1\end{aligned}$ & $\begin{array}{c}11 \text { t class } \\
1 \\
6 \text { t class } \\
3\end{array}$. & $\begin{aligned} & 15 \mathrm{t} \text { class } 1 \\
& 1 \\
& 11 \mathrm{t} \text { class } \\
& 1 \\
& 6 \mathrm{t} \text { class } \\
& 1\end{aligned}$ & $\begin{array}{c}11 \mathrm{t} \text { class } \\
1 \\
6 \mathrm{t} \text { class } \\
3\end{array}$ \\
\hline & \multicolumn{3}{|c|}{ Earthwork quantity $\left(\mathrm{m}^{3}\right)$} & & 150 & 350 & 600 & 650 & 600 & 650 \\
\hline \multicolumn{3}{|c|}{ Failure probability } & (\%) & & 3.0 & 7.1 & 10.2 & 14.2 & 19.5 & 25.8 \\
\hline \multicolumn{3}{|c|}{ Increased reliability } & $(\%)$ & & 0.36 & 1.68 & 4.83 & 7.12 & 7.90 & 8.80 \\
\hline \multicolumn{3}{|c|}{ Total reliability } & $(\%)$ & & 97.36 & 94.58 & 94.63 & 92.92 & 88.40 & 83.00 \\
\hline
\end{tabular}

(b) Second stage embankment

\begin{tabular}{|c|c|c|c|c|c|c|c|c|c|c|c|}
\hline \multicolumn{3}{|c|}{ Surcharge number } & 12 & 1 & 2 & 3 & 4 & 5 & 6 & 7 & 8 \\
\hline \multicolumn{3}{|c|}{ Embankment height (m) } & 3.00 & 3.25 & 3.50 & 3.75 & 4.00 & 4.25 & 4.50 & 4.75 & 5.00 \\
\hline \multirow{5}{*}{ 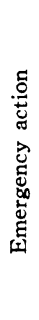 } & \multicolumn{2}{|c|}{ Method } & $\begin{array}{l}\text { Counter- } \\
\text { weight fill }\end{array}$ & $\begin{array}{l}\text { Counter- } \\
\text { weight fill }\end{array}$ & $\begin{array}{l}\text { Counter- } \\
\text { weight fill }\end{array}$ & $\begin{array}{l}\text { Counter- } \\
\text { weight fill }\end{array}$ & $\begin{array}{l}\text { Counter- } \\
\text { weight fill }\end{array}$ & $\begin{array}{l}\text { Counter- } \\
\text { weight fill }\end{array}$ & $\begin{array}{l}\text { Counter- } \\
\text { weight fill }\end{array}$ & $\begin{array}{l}\text { Counter- } \\
\text { weight fill }\end{array}$ & $\begin{array}{l}\text { Counter- } \\
\text { weight fill }\end{array}$ \\
\hline & \multirow{2}{*}{ Scale } & Height (m) & 1.20 & & 1.56 & 1.65 & 1.80 & 1.90 & 2.00 & 2.20 & 2.30 \\
\hline & & Width (m) & 6.50 & & 3.00 & 3.00 & 3.00 & 6.50 & 8.00 & 8.00 & 8.00 \\
\hline & \multicolumn{2}{|c|}{$\begin{array}{l}\text { Construction } \\
\text { equipment } \\
\text { (Bulldozer) }\end{array}$} & $\begin{array}{c}11 \mathrm{t} \text { class } \\
1 \\
6 \mathrm{t} \text { class } \\
3\end{array}$ & & $11 \mathrm{t}$ class & $\begin{aligned} & 11 \mathrm{t} \text { class } \\
& 2 \\
& 6 \mathrm{t} \text { class } \\
& 1\end{aligned}$ & $\begin{array}{l}11 \mathrm{t} \text { class } \\
\underset{2}{2} \\
6 \mathrm{t} \text { class } \\
1\end{array}$ & $\begin{array}{c}11 \mathrm{t} \text { class } \\
1 \\
6 \mathrm{t} \text { class } \\
3\end{array}$ & $\begin{array}{c}11 \mathrm{t} \text { class } \\
2 \\
6 \mathrm{t} \text { class } \\
2\end{array}$ & $\begin{array}{l}6 \mathrm{t} \text { class } \\
5\end{array}$ & $\begin{array}{c}11 \mathrm{t} \text { class } \\
4 \\
6 \mathrm{t} \text { class } \\
1\end{array}$ \\
\hline & \multicolumn{2}{|c|}{$\begin{array}{l}\text { Earthwork } \\
\text { quantity }\left(\mathrm{m}^{3}\right)\end{array}$} & 650 & & 400 & 450 & 450 & 650 & 800 & 900 & 950 \\
\hline \multicolumn{3}{|c|}{ Failure probability (\%) } & 25.8 & & 11.23 & 14.23 & 16.60 & 20.11 & 24.51 & 28.63 & 33.00 \\
\hline \multicolumn{3}{|c|}{ Increased reliability (\%) } & 8.80 & & 3.30 & 3.40 & 5.10 & 10.46 & 16.17 & 19.51 & 21.00 \\
\hline \multicolumn{3}{|c|}{ Total reliability $(\%)$} & 83.00 & & 92.07 & 89.17 & 88.50 & 90.36 & 91.66 & 90.88 & 88.00 \\
\hline
\end{tabular}


a）第 1 段階盛土について

第 1 段階盛土 $H_{\mathrm{I}}(3.0 \mathrm{~m})$ に対する破壊確率 $P_{F}$ 学 Table 1 のそれぞれの土質定数を用いて別途に計算し た結果 ${ }^{2)}$ ，25.8\% となった。また，すでにのべたように 第 1 段階の適正な破壊確率 $\left(P_{F_{\mathrm{I}}}\right)_{\text {opt }}$ が $20 \%$ と与えら れている。

さて, 最適な信頼度および対策工の種類，規模を決定 した一例として第 1 段階最終次載荷盛土（第 12 次載荷） に関する検討結果が Fig. 13 である。対策工費 $C_{M}$ の 計算においては，押え盛土や斜面勾配緩和のための用地 費が含まれていることは当然である。なお対策工として 盛土荷重軽減は非常に有効であるにもかかわらず，この 試算例では採用していない。理由は以下のとおりであ る。すなわち, 盛土荷重軽減は工期を遅延させることに 加えて, 各段階の盛土高や放置期間が地盤の圧密強度の 増加を期待したうえで決定されているため, 荷重軽減に よって盛土高を減少させることは, 当初の基本計画の根 本的な変更につながるからである。この種の変更がもた らす損失は非常に大きい。したがって今回の試算では, 対策工として斜面勾配の緩和および押え盛土工法だけに 限って試算を行った。

さて, Fig. 13 によれば 12 次載荷盛土の最適な信頼 度 $\left(A_{12}\right)_{\text {opt }}$ は $83.2 \%$ となることがわかる。一方, 高さ $3.0 \mathrm{~m}$ の盛土本体断面の信頼度は $1-P_{F \mathrm{I}}=74.2 \%$ であ ったから，これを最適信頼度にまで高めるためには，な んらかの対策工を実施して $9 \%$ の信頼度の上昇をはから なければならない。図からわかるように,この目的に対 する対策工としては押え盛土が適当となる。そして，こ れに対応する別途の計算よりその施工規模は押え盛士高 $1.2 \mathrm{~m}$ ，押え盛土幅 $6.5 \mathrm{~m}$ と計算される。

同様にして第 1 段階における他の各次載荷盛土につい ても最適な対策工の種類および規模の検討結果を一括し て Table 3 (a) に示す。表中の第 5 次載荷盛土以前 (盛 土高 $1.25 \mathrm{~m}$ 以下) においては, 計算の結果盛土本体断 面の破壊確率がほとんど 0 に等しいため, あえて対策工 を検討する必要はなかった。また, Table 3 (a) 最下段 に系全体の信頼度 $A_{j}$ が示してある。これをみればわか るように $A_{j}$ が最小となる最終次 (第 12 次) 載荷盛土さ えも $P_{F \mathrm{I}}<\left(P_{F \mathrm{I}}\right)_{\text {opt }}+\Delta P_{F}$ の関係が成立するので, $h_{1}, h_{2}, \cdots, h_{12}$ の第 1 段階盛土施工時には動態観測以外 の何んらの対策工をも考慮する必要がないことになる。

b）第 2 段階盛士について

第 2 段階についても同様の検討を行った結果をTable 3 (b) に示す。これは先に述べたように圧密期間 3 か月 を経た時点より盛土を再開してから, 計画盛土高 $5.0 \mathrm{~m}$ まで盛上げたときの検討結果である。方法論の適用は, まったく同様である。ただし Table 1 に示したように
基礎地盤の強度に対しては圧密期間中の強度増加を考慮 した ${ }^{15)}$ 。すなわち, 第 2 段階最終次載荷盛土 ( $5.0 \mathrm{~m}$ 高) に対する破壊確率 $P_{F}$ II を求めたところ $33.0 \%$ となっ た。

これに対して対策工を実施した場合，もっとも危険な 状態にある載荷盛土は, Table 3 (b) より最終次（第 8 次）となりその破壊確率は $12 \%$ であった。したがって対 策工を実施することによって低減しうる破壊確率 $\Delta P_{F \text { I }}$ は $21 \%$ となる。

一方，第 2 段階の最適な破壊確率 $\left(P_{F \text { II }}\right)_{\text {opt }}$ は $15 \%$ と与えられているので, 第 2 段階においても $P_{F \text { I }}<$ $\left(P_{F \text { II }}\right)_{\text {opt }}+\Delta P_{F \text { II }}$ の関倸が成立し, やはり第 1 段階同様 動態観測以外の対策工は考慮する必要がないと結論され る。なお，第 3 段階に関しても同様の傾向が得られた。

c) 補足事項

対策工の規模について $1 ， 2$ の補足を以下のように加 える。Table 3 (a), (b) からわかるように盛土断面が相 対的に小さいときは対策工の規模も小さく, 盛土断面が 徐々に増大するにつれて対策工の規模も増大する。この ように最適解としてきわめて常識的な結果が得られたこ とは興味深い。

実際の施工に際して, 各現場管理者は Table 3 (a), （b）のような表を施工前に作成しておき, 施工の進行状 況之常に照らし合わせながら盛土施工を行い, かりに破 壊の兆候が出現したら表中の対策工の種類, 規模を実施 すればよい。ただし，対策工のために準備すべき施工機 械, 労働力および資材は, 表にも示されているように各 次載荷盛土時で変化する。そのため前述したように, た とえば各段階盛土で対策工の規模が最大となる場合の量 をこの段階盛土中終始準備してゆく方法が現場に対応し たからであろう。

\section{6. まとめ}

土構造物の設計, 施工においてしばしば各種の動態観 測が行われる。本論文では動態観測を構造物の信頼度上 昇のための対策工として位置ゔけ, その効果を信頼度と して定量化することを試みた。すなわち，このような立 場において 2. でこの情報化施工についての概念, 特徵 および具体的な作業手段を明らかにした。3., 4. ではこ の方法論の信頼性解析に必要な信頼度関数および経済的 評価モデルを作成した。さらに 6. では実際的なモデル ケースを想定し，各段階盛土における最適な信頼度およ び最適な対策工の種類, 規模を具体的に試算してみたと ころ, その結果はいずれもきわめて常識的な推測と一致 した。一方，5. において各段階盛土の破壊予知をいか なる管理法でチェックするかについて検討を加え, その 
施工管理図も同時に提案した。

\section{参考文献}

1）松尾 稔・浅岡 顕：多段載荷による盛土の最適設計に 関する研究, 土木学会論文報告集 No. 240 , pp. 35 47, 1975.

2）松尾 稔・黑田勝彦：盛土建設のための土質調査と盛土 の安全率に関する研究, 土木学会論文報告集 No. 196, pp. $75 \sim 86,1971$.

3）松尾 稔・黒田勝彦：盛土の破壞確率を考慮した土質調 查の規模决定法について, 土木学会論文報告集 No. 198, pp. $69 \sim 81,1972$.

4）松尾 稔・黒田勝彦：盛土の設計安全率に関する研究, 土木学会論文報告集 No. 203, pp. 13～27, 1972.

5）建設省土木研究所：土木研究所資料第 635 号, 軟弱地盤 における盛土の破壊例集, 1970 .

6）不動建設研究室：石狩川支流月寒川右岸築堤試験盛土工 事概要報告書, 1968 .

7）室町忠彦・渡辺 進：野場軟弱地盤における変形観測, 鉄道技術研究報告 No. 154, pp. 1 49, 1962.

8）日本道路公団：愛甲試験盛土報告書, 1966 .
9）松尾 稔・黑田勝彦：不飽和土の土質諸係数と破壊確率 に関する一考察, 士木学会論文報告集 No. 208, pp. 65 75,1972 .

10）土木学会土木計画学研究委員会編：土木計画学講習会テ キスト 6, pp. 111 138, 1973.

11）経済調查会: 積算資料 11 月号, No. 517, 1973.

12) Lumb, P.: The Variability of Nature Soils, Canadian Geotechnical Journal, Vol. III, No. 2, pp. 74 97, 1966.

13) Lumb, P : Safety Factors and the Probabity Distribution of Soil Strength, Canadian Geotechnical Journal, Vol. 7, No. 3, pp. 225 242, 1970.

14) Hooper, J.A. and Buther, F.G. : Some Numerical Result Concerning the Shear Strength of London Clay, Geotechnique,Vol. 16, pp. 282 304, 1966.

15) Meyerhof, G.G. : Safety Factor in Soil Mechanics, Canadiam Geotechnical Journal, Vol. 7, No. 4, pp. $349 \sim 355,1970$.

16）長尾義三：土木計画序論，共立出版，1972.

17）長尾義三・松尾 稔・黑田勝彦：盛土の設計安全率决定 に関する研究, 土木学会論文報告集 No. 203, pp. 13 $27,1972$.

(1974.11.22 • 受付) 